\title{
Understanding Teachers' Attitudes Towards Young Learner Teaching: A Case Study
}

\section{Oliver Beddall}

British Council

This paper reports on a case study examining teachers' feelings about teaching young learners (YLs) in the British Council Tokyo teaching centre. A literature review is presented, outlining desirable qualities for $\mathrm{YL}$ teachers. Qualitative and quantitative research-involving an online questionnaire, attitude survey and interviews -investigates teachers' feelings about a variety of YL-related issues and finds three "groups" within the staffroom, each with a different profile and differing attitudes towards YL teaching. By identifying and analysing prevalent concerns amongst staff, recommendations for ELT managers are made to encourage effective professional development, thereby empowering less experienced teachers and promoting good practice for schools running YL programmes.

本論は、ブリティッシュ・カウンシル東京校で児童英語教育について教 師の感想を研究したケーススタディーで、児童英語教師に求められる資質 を示した文献も提示する。オンラインでのアンケートとインタビューとい う質的・量的研究手法を用いて、様々な問題点に対する教師の感情を調 査した結果、異なつた経歴と態度を持つ3つのグループに分けられること がわかった。教員が抱える問題点を発見・分析することで、ELT運営に対 して職務能力向上のための提案を行う。また、このような研究は、経験の 少ない教員には能力強化に繋がり、児童英語プログラムを持つ学校にお いては、よりよい授業を提供する指針となる。

Y oung Learners (YLs), defined in this paper as children of 6-17 years old, are the fastest-growing segment of the ELT market (CUP Annual Report, 2014). Language teaching organisations worldwide are adapting their operations to meet this demand, and teachers are increasingly being expected to teach classes of children, despite the fact that the majority of TEFL qualifications focus on adults.

The British Council (BC) Tokyo runs a large number of English language courses both in-house and off-site. In addition to a plethora of adult courses, YL courses have also been delivered in elementary, junior, and senior high schools for many years, albeit by a specialist group of YL teachers. At the time of writing, however, the $\mathrm{BC}$ was preparing to offer its own in-house YL classes for the first time. How the wider staffroom would react to teaching YLs was unknown, as there was a general lack of YL teaching experience amongst the existing body of teachers.
Faced with this unique situation, this research sets out to better understand teacher attitudes towards teaching YLs and to understand how such innovations can be best supported from a managerial perspective.

\section{Literature Review}

I will begin by discussing the theory underpinning the measurement of attitudes, which forms the basis of this study.

\section{Measuring Attitudes}

In any educational institution it is the teachers who are charged with delivering the curriculum to the students. Understanding teachers' attitudes towards their work is therefore of key importance in understanding and improving the quality of education provision (van Aalderen-Smeets \& van der Molen, 2013). It is well-known that teachers' attitudes can impact directly on teaching and learning in the classroom and this has been demonstrated in numerous studies which have found links between teacher attitudes and characteristics such as confidence levels, beliefs about self-efficacy, and different approaches to pedagogy (Weinburgh, 2007).

Consequently, with any pedagogical innovation, there needs to be an accompanying change in attitudes on the part of those involved (Karavas-Doukas, 1996). An understanding of teachers' attitudes can be used to help manage innovation and develop an appropriate provision for in-service teacher development (Breen, 1991).

Tools used to measure attitudes are commonly referred to as inventories, surveys, instruments, or measurement scales. Of the many that have been employed, Likert scales are the most common method of collecting data (Lovelace \& Brickman, 2013). Respondents indicate the extent of their agreement or otherwise with a given statement on a numerical scale that usually spans five points. This, in turn, allows for quantitative analysis of the data.

In one of the few existing studies of teacher attitudes within the field of ELT, Karavas-Doukas 
describes the analysis of the data from Likert scales and the creation of attitude scores:

Depending on the respondent's endorsement of each statement, a particular score is rendered. The total score, which is calculated by adding up the scores for each item, places the respondent on a continuum from least favourable to most favourable. Usually, the higher the score, the more favourable the respondent's attitude. (1996, p. 190)

Thus, with a combination of judiciously-chosen attitude statements, a picture of teacher attitudes towards a particular phenomenon can be created.

The field of measuring attitudes is not without its challenges, however, and existing studies in other fields have been criticised for a failure to properly define attitude and to distinguish it from related concepts such as opinion or drive, resulting in difficulty interpreting and generalising from the results (Ajzen, 2001).

Having discussed the measurement of attitudes, I will now present the research methodology.

\section{Methodology}

\section{Case Study}

A case study approach was adopted for this research - the study and detailed description of one particular aspect of a case (Richards, 2003). Through this I will offer a detailed investigation of the individuals in the specific context of this study, an approach considered preferable to theoretical generalisations applied to a specific situation (Cohen, Manion, \& Morrison, 2007).

\section{Participants}

The participants in the study were 26 full-time and 11 part-time teachers at the BC Tokyo, aged between 27-48. Their teaching experience varied widely, ranging from two years post-certificate qualification to those who held both a diploma and master's qualification in addition to many years of service. Of all participants, fewer than one third had any recent experience of teaching YLs.

\section{Procedure}

\section{Attitude Statements}

In planning the study, I took as my inspiration the Karavas-Doukas paper (1996) cited in the literature review, in which attitude scales were used to collect data from participants in a questionnaire.
The first step was to generate a set of attitude statements capable of gauging teachers' attitudes to YL teaching.

\section{Initial Survey}

To generate the statements, a survey was first set up using surveymonkey.com (Appendix A), trialled and sent to all teaching staff by email. Teachers were asked to provide one simple piece of information: whether they would be happy to teach YLs and, most importantly, why.

\section{Attitude Statements and Questionnaire}

Opinions given in the survey were analysed using a process of inductive coding (Burns 2009), where full responses were scanned multiple times looking for emerging categories. These categories were distilled further into individual attitude statements that were representative of the opinions put forward in the survey. Likert scales were used as the measurement scale, whereby each response was assigned a numerical value (strongly disagree $=1$ and strongly agree $=5$ ), which were then used to calculate an attitude score for individual teachers. A mix of positive and negative statements (10 of each) was included to control for bias, and each statement was worded in such a way that was demonstrably either positive or negative so that statistical analysis would reliably reflect the intention of the respondent.

For example, respondents who answered strongly agree to a positively-worded statement would earn five points, whereas answering strongly agree to a negatively-worded statement would result in the loss of five points. Respondents with a high final score could therefore be said to have strong positive attitude towards teaching YLs, whilst the opposite would be true of respondents with a low or negative score.

The finished attitude statements were then randomised and fashioned into the final questionnaire (Appendix B). The completed anonymous attitude survey was trialled and distributed to teachers.

\section{Triangulation}

Results from the questionnaire were triangulated by a series of semi-structured interviews (Burns, 2009) with three volunteers from amongst the respondents. In these interviews, teachers were asked for their opinions on issues emerging from the research, in order to provide a deeper insight into the significance of results. 


\section{Results and Analysis}

I will now give a summary of results from the questionnaire, followed by a discussion of findings.

\section{Questionnaire}

The questionnaires received a response rate of $73 \%$ and complete responses can be found in Appendix C.

\section{The Group}

Overall, there were a relatively small number of attitude statements that elicited negative responses. However, some negativity was evident (see Figure 1), and this included, most notably, $74 \%$ of teachers who believed that YL teaching can be stressful and 56\% who expressed concern about dealing with demotivated children. A minority of $30 \%$ of teachers were not confident about classroom discipline and further $30 \%$ would not welcome YL classes on their teaching schedule.

There was a certain amount of unanimity in opinion amongst teachers on certain points. A high number of teachers (85\%), for example, believed that YL teaching can be very rewarding and many also saw everyday classroom interaction with YLs as enjoyable. A similarly high number had an interest in pedagogy outside linguistics and saw themselves as suitable for YL teaching. Despite these positives, there was nevertheless consensus amongst teachers (74\%) that YL teaching can be stressful.

There was no agreement on the benefits of YL teaching experience to job security, perhaps surprisingly given the upward trend worldwide in $\mathrm{YL}$ teaching.

\section{Individual Teachers}

In the revealing graph of individual teachers' attitude scores shown in Appendix D it can be seen that most individuals were positive about $\mathrm{YL}$ teaching. What is striking, however, in direct contrast to the general positivity, is the small but acutely negative cluster of responses from a number of teachers, which I will discuss later.

Having developed a snapshot of teachers' general orientation towards teaching YLs, a comparison of individual teachers' responses was made in order to identify any groups amongst the respondents. The analysis indicated that teachers fell into three camps.

\section{Group 1. The Typical Teacher}

Teachers in this group each gave very similar responses to one another in the attitude survey. This
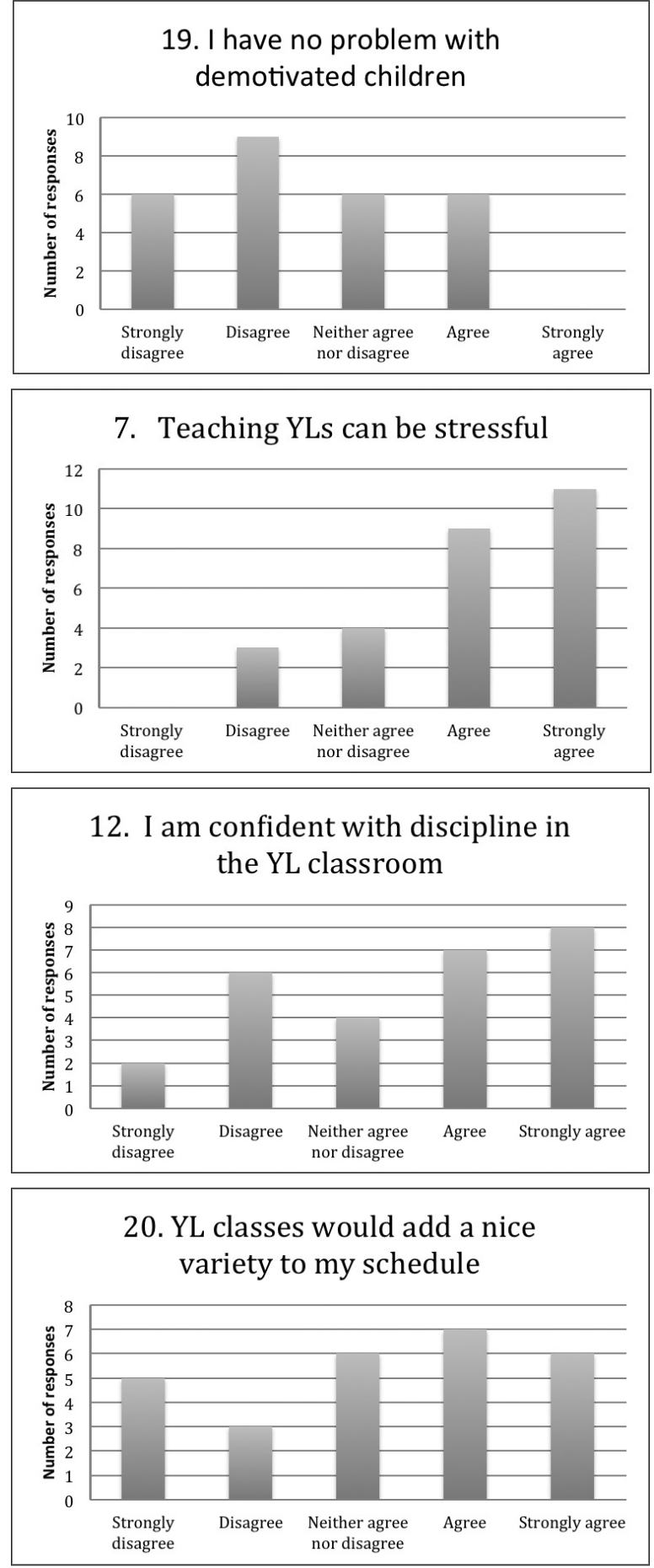

Figure 1. Questionnaire Statements that Elicited Negative Responses

included almost half of all respondents (44\%), and for this reason I labelled teachers in this group as the "typical teacher" (see Appendix E). They were 
positive about YL teaching. They viewed it as interesting and rewarding, felt it would add a nice variety to their schedule and were motivated by the greater job security that may come with the experience.

They liked children and enjoyed YL classroom interaction. Some had an interest in pedagogy related to areas outside linguistics and most were confident with discipline in the classroom. Their major concerns were with demotivated learners and stress surrounding YL teaching.

As one teacher commented in an interview:

"I don't know, I just prefer teaching kids to adults. They're more honest, you know? It's not that it isn't stressful-it is, and sometimes it's a real pain, especially when they can't be bothered, and I have trouble dealing with those kinds of kids sometimes-but on the whole I love it."

\section{Group 2}

Teachers in the second group $(33 \%$ of respondents, 9 teachers) were found to differ from the "typical teacher" on a number of points. While the typical teachers thought largely alike, the defining characteristic of Group 2 was that they did not. Teachers in this group each had their own unique mix of concerns, namely dealing with demotivated children, classroom management, discipline, stress, and dealing with parents. Despite these varied concerns, however, it is noticeable that $89 \%$ of respondents in this group believed that YL teaching could be very rewarding.

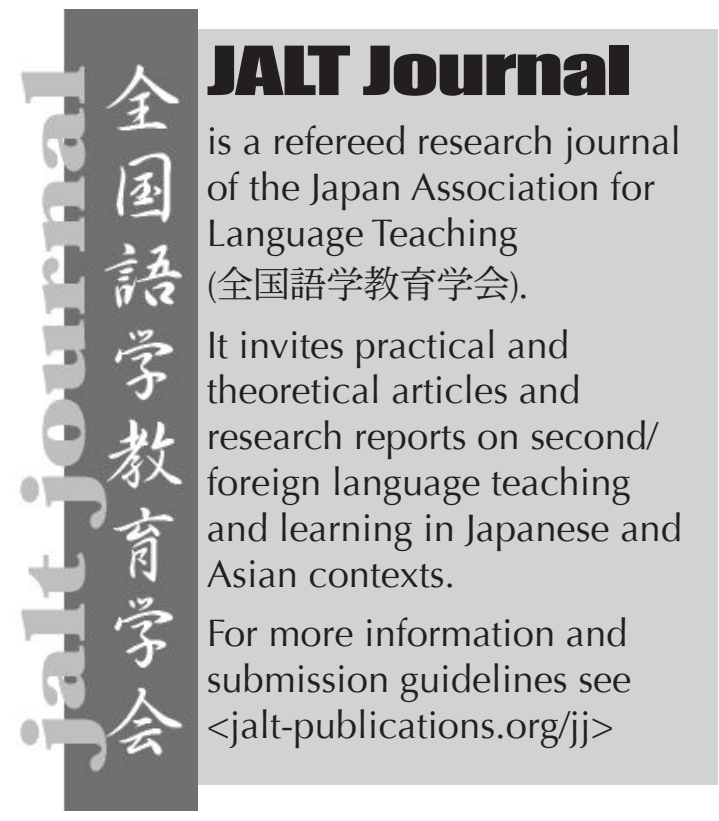

\section{Group 3}

The third group made up $23 \%$ of the staff room (6 teachers). The overwhelming characteristic of this group was that no teachers had any interest in teaching YLs and 83\% said that this feeling would not change even with sufficient training. $67 \%$ claimed to be put off by issues surrounding discipline in the classroom and even more dismissive of the variety it could add to their schedule.

It is a complex picture, however, with significant variation in opinion within the group. For example, some teachers claimed to like children $(33 \%)$ and even believed that YL teaching can be rewarding (50\%). Although none of them saw YL teaching as linked to job security, $67 \%$ believed that relevant experience would improve their career prospects.

\section{Discussion and Recommendations Discussion}

The above analysis of teacher attitudes towards teaching YLs in this staffroom leads to a number of interesting interpretations, not least of which is the emergence of three groups of teachers. It should be noted first and foremost that it was encouraging to see the existence of Group 1, who were wholly positive about $\mathrm{YL}$ teaching. The fact that this group still had concerns over stress and discipline in the classroom (the two of which may well be related) in spite of their positive orientation, points to a potential area of focus for any teacher training initiatives.

The existence of Group 3, with no interest in YL teaching, was perhaps to be expected in a staffroom of this size. However, the intensity of their feelings was something of a surprise, stating for instance that they would not want to teach YLs even with the provision of appropriate training. The emotion behind these feelings was evident in the following comment from one teacher in an interview:

"Look, some people just really, really don't want to teach kids - and they shouldn't have to. They're not suitable. The 'A' in CELTA stands for Adults! They never signed up to teach kids."

With such apparent resistance, the inevitable question for managers is whether it would ever be advantageous to oblige teachers to teach YLs. The implication for students, parents and the reputation of the organisation of placing disinterested teachers in the YL classroom hardly need spelling out. 
Sat in-between the positivity of Group 1 and the negativity of Group 3 was the second group, whose mixed feelings may prove to be the most interesting of all. Teachers in Group 2 harboured a number of concerns around some of the more fundamental aspects of YL teaching (e.g., classroom management, motivation), most likely due to a lack of experience. They are, in other words, novice YL teachers, which is to be expected in any organisation where $\mathrm{YL}$ teaching is not the primary offer.

However, despite their concerns, it is important to note the positive orientation of the group. Whereas those in Group 3 had displayed resistance to professional development in the YL arena, the positivity of Group 2 strongly suggests that they would react well to training. With all things being equal, fears and concerns will inevitably be foregrounded in teachers minds, but this insight into the natural positivity of Group 2 is significant because it presents management with an opportunity to address training gaps and empower enthusiastic YL teachers in waiting.

This is perhaps best summed up by the following comment in interview:

"We're all up for it [YL teaching], you know. I don't think that's an issue. But for me personally, I just haven't really done much of it before and that kind of makes me a bit nervous."

This need for basic training should not be underestimated. When considered in the context of the wider TEFL industry, where certificate and diploma courses are targeted almost exclusively at adult teaching, it stands to reason that teachers such as those in Group 2 will have concerns about being sent into the YL classroom-concerns which, if not properly addressed, may ultimately manifest themselves in resistance. Furthermore, it is conceivable

\section{JALT Apple Store

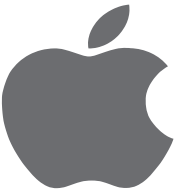 \\ Don't forget, JALT membership brings added bonuses, such} as discounted Apple products through the JALT Apple Store. $<$ jalt.org/apple $>$ that the feelings of stress reported by all participants, even the most positive, and as highlighted by Verity (2000), might be somewhat alleviated with training.

Garton, Copland, and Burns (2011, p. 20) echo this point thus:

"The needs of in-service teachers are particularly acute, given that many did not start their careers as teachers of English or as teachers of young learners".

The question that produced the biggest mix of responses was \#20: 'YL classes would add a nice variety to my schedule'. Although this is clearly an issue specific to this particular context, it is nonetheless likely that that teachers working in similar ELT organisations may face similar issues. One teacher commented in interview:

"I quite enjoy teaching kids from time to time, but I just don't want to be labelled as a kids' teacher... I don't want a schedule of only kids."

This suggests that further investigation is warranted into perceived implications of YL teaching in regards to teacher allocation and class scheduling. Teachers may, for example, welcome YL teaching providing it does not dominate their schedule. Should this feeling be widespread, managers in ELT organisations might be well advised to be open and transparent about their scheduling policies and maintain a dialogue with teachers about this.

\section{Limitations}

The anonymous nature of the questionnaires comes with inherent limitations, such as the lack of biographical data, which may have offered insight into responses. For this reason it was also not possible to compare the responses of experienced and inexperienced YL teachers, which would have made for an interesting comparison.

\section{Recommendations}

Considering the opportunities suggested in the above analysis, I would suggest the following steps to be taken by an ELT organisation wishing to promote best practice in YL teaching:

1. Teacher induction should cover YL teaching and theory. "Core" theoretical content might include child developmental stages, Vygotsky's Zone of Proximal Development, L1 literacy, and the language curriculum in the local education system. 
2. Practical qualifications such as the CELTA YL Extension or CiSELT should be actively encouraged and financially supported where possible.

3. A regular programme of in-service training should be established to cover YL teaching issues.

4. Peer-observation should be promoted as an effective way to support teacher development and reflection.

\section{Conclusion}

This research has shown that the staffroom in this organisation was made up largely of teachers with a positive orientation toward teaching YLs. Despite feelings at both ends of the spectrum, there was a significant body of teachers in the middle who, in spite of some insecurities, were willing to take on YL classes. Their concerns were representative of a predictable training gap comprising perennial issues such as classroom management and discipline, and there appears to be a good chance that targeted in-service training could empower these teachers into becoming confident and enthusiastic YL practitioners.

From a management perspective, a willingness to engage with and understand teachers' attitudes towards YLs may help those working in similar contexts to identify such issues in the staffroom, and potentially uncover training opportunities with the potential to make a lasting impact on the enthusiasm and skillset of YL teachers.

\section{References}

Ajzen, I. (2001). Nature and operation of attitudes. Annual Review of Psychology, 52, 27-58.

Breen, M. P. (1991). Understanding the language teacher. In R. Phillipson, E. Kellerman, L. Selinker, M. Sharwood Smith, \& M. Swain (Eds.), Foreign/second language pedagogy research. Clevedon, Avon: Multilingual Matters.

Burns, A. (2009). Doing action research in English language teaching: A guide for practitioners. London \& New York: Routledge.

Cambridge University Press Annual Report (2014). Retrieved from <http://www.cambridge.org/about-us/ who-we-are/annual-report/english-language-teaching-elt>

Cohen, L., Manion, L., \& Morrison, K. (2007). Research methods in education. New York: Routledge.

Garton, S., Copland, F., \& Burns, A. (2011). Investigating global practices in teaching English to young learners. London: British Council.

Karavas-Doukas, E. (1996). Using attitude scales to investigate teachers' attitudes to the communicative approach. ELT Journal, 50(3), 187-198.
Lovelace, M., \& Brickman, P. (2013). Best practices for measuring students' attitudes toward learning science. Life Sciences Education, 12, 606-617.

Richards, K. (2003). Qualitative inquiry in TESOL. New York: Palgrave Macmillan

van Aalderen-Smeets, S., \& van der Molen, J. W. (2013). Measuring primary teachers' attitudes toward teaching science: Development of the dimensions of attitude toward science (DAS) instrument. International Journal of Science Education, 35(4), 577-600.

Verity, D.P. (2000). Side affects: The strategic development of professional satisfaction. In J. P. Lantolf (Ed.), Sociocultural theory and second language learning (pp. 179-197). Oxford: Oxford University Press.

Weinburgh, M. (2007). The effect of Tenebrio obscurus on elementary preservice teachers' content knowledge, attitudes, and self-efficacy. Journal of Science Teacher Education, 18, 801-815.

Oliver Beddall is a teacher trainer and academic manager currently based at the British Council in Cairo, Egypt. He spent four years teaching in Tokyo, where this research was conducted. He has published various papers, presented at major international conferences and holds a master's

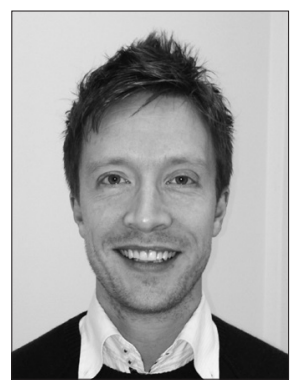
degree in TESOL from Aston University. Email: <olibeddall@gmail.com>.

\section{Appendices}

Appendix A, Initial Survey; Appendix B, Questionnaire; Appendix C, Graph of Responses; Appendix D, Teacher Attitude Score; and Appendix E, The "Typical Teacher" can all be found in the online version of this article at <http://jalt-publications.org/tlt $>$.

\section{Is your membership due for renewal?}

$$
\begin{aligned}
& \text { Check the label on the } \\
& \text { envelope this TLT came in for } \\
& \text { your renewal date, then go to } \\
& \text { <jalt.org/main/membership> } \\
& \text { and follow the easy } \\
& \text { instructions to renew. Help us } \\
& \text { to help you! Renew early! }
\end{aligned}
$$

